Idan Dershowitz*

\title{
The Valediction of Moses: New Evidence on the Shapira Deuteronomy Fragments
}

https://doi.org/10.1515/zaw-2021-0001

\section{Introduction}

In this article, I offer new evidence and arguments against the prevailing theory that Wilhelm Moses Shapira forged his infamous Deuteronomy fragments. ${ }^{1}$

I begin by providing historical background on Shapira and his manuscripts. Next, I discuss the negative evaluation of the manuscripts in 1883, review existing objections to the arguments for forgery, and offer new objections of my own. I then address more recent paleographic arguments against the authenticity of the manuscripts and show that they rest on dubious evidence and are methodologically problematic. After this, I turn to some overlooked personal documents of Shapira's, which challenge the consensus forgery narrative. I conclude with a summary of the outcomes of my philological analysis of the text contained in the Shapira manuscripts, which I call »The Valediction of Moses«: Far from being derivative of Deuteronomy, this text is, in fact, Deuteronomy's ancient forebear.

\section{Background}

Wilhelm Moses Shapira was born in 1830 to a Jewish family in the city of KamianetsPodilskyi, in what is now Ukraine. In his mid-twenties, he emigrated to Ottoman

1 I am indebted to the Julis-Rabinowitz Program on Jewish and Israeli Law at Harvard Law School and to the Harvard Society of Fellows for their support. I am grateful to the participants of the workshop on this topic held at Harvard in June 2019, all of whom gave generously of their time, and whose comments and critiques greatly improved this work. I thank Avishay Ben-Sasson Gordis, Nachum Dershowitz, Noah Feldman, Shimon Gesundheit, Jonathan Gould, Abram Kaplan, Maria Metzler, Eric Nelson, Ronit Prawer, Konrad Schmid, Jeffrey Stackert, David Stern, Andrew Teeter, and Shani Tzoref for their many helpful comments, whether on drafts of this article or in conversation. I am also grateful to Maria Metzler for copyediting this manuscript.

*Kontakt: Idan Dershowitz, University of Potsdam, Am Neuen Palais 10, 14469 Potsdam, Germany, E-Mail: dershowitz@uni-potsdam.de

Ә Open Access. (c) 2021 Dershowitz, published by De Gruyter. (c) BY This work is licensed under the Creative Commons Attribution 4.0 International License. 
Palestine, converting to Christianity along the way. Some time after settling in Jerusalem, he opened a shop in the Old City on Christian Street, ${ }^{2}$ where he sold assorted novelties such as postcards, pressed flowers, and engraved olive wood. In a back room, he kept his more precious wares-manuscripts and antiquities.

Shapira was involved in scandal when Moabite pottery figurines that he had sold to the Prussian government were found to be inauthentic by the French emissary and archaeologist, Charles Simon Clermont-Ganneau. ${ }^{3}$ Following this affair, Shapira traveled to Egypt and Yemen, where he acquired many manuscripts, which he then sold to various institutions and collectors around the world. The British Museum alone purchased hundreds of manuscripts from Shapira. ${ }^{4}$

According to Shapira's testimony, it was in the summer of 1878 that he first heard about some ancient leather manuscript fragments that had been discovered by Bedouins in a cave near the Dead Sea, above Wadi al-Mujib. With the help of Sheikh Mahmud Erekat of Abu Dis, Shapira acquired these fragments in several lots. Eventually, he came to possess what appears to have been portions of three manuscripts: one nearly complete, one somewhat less so, and a small decayed fragment of a third..$^{5}$ These manuscripts were said to have been found wrapped in linen bundles and covered with a bituminous substance. ${ }^{6}$

\section{The Discovery Story}

Shapira's discovery story attracted immediate skepticism. The great philologist, Archibald Sayce, wrote at the time:

It is really demanding too much of Western credulity to ask us to believe that in a damp climate like that of Palestine any sheepskins could have lasted for nearly 3,000 years, either above ground or under ground, even though they may have been abundantly salted with asphalte from the Vale of Siddim itself. ${ }^{7}$

2 This alley is known today as Christian Quarter Street.

3 While several associates of Shapira's had confessed to the crime of forgery, they all later retracted their confessions on the grounds that Clermont-Ganneau-a high-ranking diplomathad extracted them by a mix of bribery, threats, and brutal violence (see »The Shapira Collection, « The Athenæum [March 7, 1874]: 326f.). Nevertheless, it is certain that many, if not all, of the Moabite figurines were modern forgeries.

4 George Margoliouth, Catalogue of the Hebrew and Samaritan Manuscripts in the British Museum, vol. 4 (London: The British Museum, 1935), viii-ix.

5 British Library Ms. Add. 41294, »Papers relative to M. W. Shapira’s forged MS. of Deuteronomy«: 29.

6 BL Ms. Add. 41294, 3.

7 Archibald H. Sayce, »Correspondence: The Shapira Mss. of Deuteronomy, « The Academy 589 
Of course, the very details that made Shapira's account preposterous to his peers are what make it ring so true following the discovery of the Dead Sea Scrolls some seventy years later. These too were found by Bedouin shepherds in caves near the Dead Sea. Strikingly, many of the Dead Sea Scrolls were also wrapped in linen bundles $^{8}$ and bedaubed with a sticky black substance that imbued the linen. ${ }^{9}$

Given that Shapira's story had been deemed the fabrication of a fabulist, when the Dead Sea Scrolls were alleged to have been discovered under nearly identical circumstances, some scholars made the obvious inference: The Dead Sea Scrolls, too, were a fraud.

Solomon Zeitlin, one of the world's leading experts on the Second Temple period, was resolute in his denial of the scrolls' antiquity. In 1950, he proclaimed:

[T]he Isaiah Scroll, Habakkuk Commentary and the other scrolls are not of great antiquity. [...] The scrolls themselves are not of any value. The Isaiah Scroll was copied by an uneducated Jew who did not comprehend the meaning of the words he was writing. [...] Professor Albright entitles his article "Are the "Ain Feshkha Scrolls a Hoax?« to which I answered in the affirmative. I reiterate that, the Dead Sea Scrolls are a hoax. ${ }^{10}$

Around the same time, Zeitlin wrote the following regarding the parallels between the Dead Sea Scrolls and Shapira's manuscripts:

Professor Burrows seems to have forgotten the affair of Shapira, who produced a manuscript of the Book of Deuteronomy, written on parchment in archaic Hebrew script. He stated that he procured it from a Bedouin who told him that he found it in a cave (again a Bedouin and a cave). Scholars and experts of the British Museum were convinced of its authenticity until it was discovered to have been produced by Shapira himself over a period of twenty years. Thus "the Bedouin and the cave« became a myth. ${ }^{11}$

(August 24, 1883): 116f.: 117. With regard to the linen bundles, an article in The Times contended: »The mention of the linen seems somehow a mistake since believers in leather can hardly be expected to assign equal staying power to mere flax, « The Times (August 21, 1883): 7.

8 See, e. g., Na'ama Sukenik, »The Temple Scroll Wrapper from Cave 11. MS 5095/2, MS 5095/4, MS 5095/1, « in Gleanings from the Caves: Dead Sea Scrolls and Artefacts from the Schøyen Collection, ed. Torleif Elgvin et al. (London: T\&T Clark, 2016): 339-350.

9 Roland de Vaux, "Post-Scriptum: La Cachette des Manuscrits Hébreux, « RB 56/2 (1949): 234-237; Joan E. Taylor, »Buried Manuscripts and Empty Tombs: The Qumran Genizah Theory Revisited, « in `Go Out and Study the Land` (Judges 18:2): Archaeological, Historical, and Textual Studies in Honor of Hanan Eshel, ed. Aren M. Maeir et al. (Leiden: Brill, 2012): 269-315: 280; $314 \mathrm{f}$. 10 Solomon Zeitlin, »The Hebrew Scrolls: Once More and Finally, «JQR 41/1 (1950): 1-58: 50. For a supporting view, see Oskar K. Rabinowicz, »The Shapira Forgery Mystery, « JQR 47/2 (1956): 170-195: 182.

11 Solomon Zeitlin, »The Alleged Antiquity of the Scrolls, «JQR 40/1 (1949): 57-78: 67. 
We know today that Zeitlin was mistaken; the Dead Sea Scrolls are both ancient and of momentous consequence. This being the case, Zeitlin's logical maneuver must now be reversed: Rather than Shapira's ostensibly false story casting doubt on the authenticity of the Dead Sea Scrolls, the securely accurate details of the later discovery narrative lend credibility to Shapira's account. ${ }^{12}$

\section{The Original Verdict (and a Recent Update)}

In 1883, Shapira took his manuscripts on a European tour, which commenced in Leipzig. Hermann Guthe, then a Privatdozent of Old Testament exegesis at the university there, reported: "Shapira wished to persuade a group of skilled scholars, maybe even scholars who did not agree on one another's scientific assumptions and opinions, to collectively examine the manuscript and to publish their opinions concerning its value and especially its authenticity. ${ }^{13}$

Shapira's wish was granted when several of the world's leading scholars gathered in Berlin to examine his manuscripts. These giants, however, reportedly spent a mere ninety minutes on the investigation before reaching their unanimous verdict:

This committee consisted of Professor Dillmann, of the Hebrew Chair; Professor Sachau, the distinguished Orientalist; Professor Schrader, the celebrated Assyriologist; Professor Ermann, another Hebrew scholar; and Dr. Schneider, who in the years between 1852 and 1860 compiled the valuable catalogue of Hebrew books, \&c., in the Bodleian library at Oxford.

The committee met at the house of its convener, Professor Lepsius, on the 10th of July last; and, while Mr. Shapira, of Jerusalem, was waiting in expectant trepidation in an adjoining room, spent exactly one hour and a half in a close and critical investigation into the character of his goat-skin wares. At the end of the sitting they unanimously pronounced the alleged codex to be a clever and impudent forgery. There was some thought of calling in a chemist to look at the matter from his particular point of view; but so satisfied were the committee with the general internal evidence against the presumption of the antiquity of more than 2,000 years claimed for the strips, that they deemed it unnecessary to call for further proof. ${ }^{14}$

12 For more on these points, see already Jacob L. Teicher, »The Genuineness of the Shapira Manuscripts, "The Times Literary Supplement (London) (March 22, 1957): 184; Menahem Mansoor, "The Case of Shapira's Dead Sea (Deuteronomy) Scrolls of 1883, « Wisconsin Academy of Sciences, Arts and Letters 47 (1958): 183-225; John Marco Allegro, The Shapira Affair (New York: Doubleday, 1965); Helen G. Jefferson, »The Shapira Manuscript and the Qumran Scrolls, « Revue de Qumrân 6/3 (1968): 391-399; Colette Sirat, »Les Fragments Shapira, « Revue des Études Juives 1-2 (1984): 95-111; Shlomo Guil, »The Shapira Scroll Was an Authentic Dead Sea Scroll, «PEQ 149/1 (2017): 6-27.

13 Hermann Guthe, Fragmente einer Lederhandschrift enthalten Mose's letzte Rede an die Kinder Israel (Leipzig: Breitkopf \& Härtel, 1883), $1 \mathrm{f}$. My translation.

14 »The Shapira Manuscripts, « The Times (August 28, 1883): 5. 
In parallel, Guthe worked with Eduard Meyer on the manuscripts, having spent a few workdays with them in Shapira's hotel room. These were not ideal conditions, and time was short. Guthe remarked that due to the poor light during thunderstorms, he and Meyer were unable to check their preliminary transcription of several columns. ${ }^{15}$ Nevertheless, Guthe published a booklet on the topic the very next month, and although he was said to have initially believed the manuscripts to be authentic, ${ }^{16}$ he too ultimately pronounced them a forgery.

Shapira traveled from Germany to England, where he offered his manuscripts to the British Museum for a reported million pounds. ${ }^{17}$ The British government appears to have seriously considered this offer, pending authentication of the manuscripts. This task was delegated to Christian David Ginsburg, who spent several weeks studying the documents, publishing regular updates in the Athenæeum. ${ }^{18}$ Meanwhile, two fragments were placed on display, drawing huge crowds, including the Prime Minister, William Gladstone, who met Shapira in person to discuss the matter. ${ }^{19}$

While Ginsburg was working on transcribing and evaluating the manuscripts, Clermont-Ganneau arrived at the museum, having traveled to England expressly to see the fragments-which he was certain must be forgeries-with his own eyes. ${ }^{20}$ He requested access to the manuscripts but was allowed only a few minutes with two or three of the many fragments. ${ }^{21}$ This, according to the staff of the British Museum, was with the express proviso that Clermont-Ganneau refrain from publishing a report until Ginsburg had released his. ${ }^{22}$ The next morning, however, Clermont-Ganneau announced to the press that the manuscripts were forgeries. After this, Clermont-Ganneau was refused further access to the manuscripts. In his own words:

15 Guthe, Lederhandschrift, 21.

16 »Mr. Shapira's Manuscript, « The Times (August 8, 1883): 11.

17 BL Ms. Add. 41294, 24; The Times (August 3, 1883): 9.

18 Christian David Ginsburg, »The Shapira Ms. of Deuteronomy, « The Athenæum 2911 (August 11, 1883): 178 f.; idem, »The Shapira Ms. of Deuteronomy, « The Athenæum 2912 (August 18, 1883): 206; idem, »The Shapira Ms. of Deuteronomy, « The Athenæum 2913 (August 25, 1883): 242-244; idem, »The Shapira Ms. of Deuteronomy, « The Athenæum 2915 (September 8, 1883): $304 \mathrm{f}$.

19 »The Shapira Manuscript, « The London Evening Standard (August 14, 1883): 3.

20 Charles Simon Clermont-Ganneau, "Mr. Shapira's Manuscripts, "The Times (August 21, 1883): 8: "I will not conceal the fact that I entertained in advance, most serious doubts as to their authenticity, and that I came here in order to settle these doubts. But I thought it my duty to pronounce no opinion until I had seen the originals."

21 Ibid.

$22 »$ From our London Correspondent (by Private Wire), « The Manchester Guardian (September 6, 1883): 5. 
In these circumstances, the object of my mission became extremely difficult to attain, and I almost despaired of it. I did not, however, lose courage. I set to work with the meagre means of information which were at my disposal:-(1) The hasty inspection of two or three pieces which M. Ginsburg had allowed me to handle for a few minutes on my first visit; (2) the examination of two fragments exposed to public view in a glass case in the manuscript department of the British Museum-a case very ill-lighted and difficult of approach, owing to the crowd of the curious pressing round these venerable relics. ${ }^{23}$

Yet this »hasty inspection « and poorly lit glimpse sufficed for Clermont-Ganneau not only to establish the manuscripts' definite inauthenticity, but even to find the »smoking gun «-the material source of the forged manuscripts. He proclaimed that the leather fragments had been cut from the bottom margins of eastern Torah scrolls and added an unsubtle insinuation: "Mr. Shapira must be well acquainted with [such scrolls], for he deals in them. ${ }^{24}$ Clermont-Ganneau had not, however, had an opportunity to compare any Torah scrolls side-by-side with Shapira's fragments. He therefore wrote:

I advise all the impartial scholars [...] to whom may be permitted an examination which is denied to me (I know not, or rather, I know very well why) to take the suspected strips, and to lay them against the lower edge of one of the synagogue rolls preserved at the British Museum. [...]

(1). To ascertain whether, by chance, there does not remain on the upper portion of the strips traces of the tails of the square Hebrew letters, especially of the final letters which, as we know, descend below the normal line. (2). To see if the back of the leather does not materially differ in appearance from the face of it; and whether it has not been left in the raw state, as on the synagogue rolls. (3). To take the average height of all the strips, in order to obtain from them the greatest height, which will enable us to determine the height of the original margin of the roll (or the rolls) that supplied the forger. I can at once affirm that on this roll the columns of square Hebrew characters were from 10 to $11 \mathrm{~cm}$ in breadth, and were separated by blank intervals of about $4 \frac{1}{2} \mathrm{~cm}$ in breadth. (4). To ascertain the description of the leather, and above all of the thread in the seams. ${ }^{25}$

When Clermont-Ganneau was taken up on this challenge, the findings did not match his predictions:

M. Clermont Ganneau [...] has published a letter, in which he claims to have discovered that the manuscript is a forgery, and that it was written on slips cut from the margin of a comparatively modern synagogue-roll. [...] But the portion of the Deuteronomy manuscript

23 Clermont-Ganneau, »Manuscripts«: 8.

24 Ibid.

25 Charles Simon Clermont-Ganneau, »Mr. Shapira’s Manuscripts, « The Times (August 21, 1883): 8. 
examined by the present writer was written on leather of a thicker character, differing very considerably from that usually employed in synagogue-rolls. ${ }^{26}$

It should be noted that no one found traces of any letters on the manuscripts, either.

Shortly after the pronouncement of Clermont-Ganneau, Ginsburg published his report, in which he agreed with Clermont-Ganneau's assessment. ${ }^{27}$ Clermont-Ganneau and Ginsburg based their verdict on a number of factors, all of which have been ably addressed in previous publications. ${ }^{28}$ I will therefore focus my analysis on an addendum to their argument, which has been offered by Chanan Tigay in a recent book on the Shapira manuscripts.

Tigay argues that he has found a Torah scroll that was once owned by Shapira, from which Shapira himself removed the bottom margin for the purpose of preparing his forged documents, precisely as theorized by Clermont-Ganneau and Ginsburg:

When I returned the following day, I discovered part of a Torah scroll containing eleven columns from the Book of Numbers [...] And the entire lower margin, running to eighteen inches, had been sliced off with a sharp knife, taking with it the bottom edges of several words. [...]

So I contacted several more experts-scholars and scribes in the United States and Israel, people who study and write Torah scrolls-to see if anyone could disabuse me of my growing suspicions. None could. Though each was able to conceive of reasons someone might remove such a large section from the lower margin of a Torah scroll, not a single one had ever seen it done.

Which left only one option: Shapira. [...]

After traveling to seven countries on four continents over the course of four long years, I had, at last, found the smoking gun. ${ }^{29}$

The scroll to which Tigay refers is held at the Sutro Library in San Francisco and is catalogued as Brinner 11. See photographs below:

26 The Daily News (August 22, 1883): 3; no byline. This is cited in Mansoor, »Shapira’s Dead Sea Scrolls«: 197.

27 There was much dispute as to which of the two scholars was first to conclude that the manuscripts had been cut from oriental Torah scrolls. See »From our London Correspondent (by Private Wire), « The Manchester Guardian (September 6, 1883): 5.

28 Teicher, "Genuineness of Shapira«: 184; Mansoor, "Shapira’s Dead Sea Scrolls«: 183-225; Allegro, Shapira Affair; Jefferson, »Shapira Manuscript«: 391-399; Guil, »Shapira Scroll«: 6-27.

29 Chanan Tigay, The Lost Book of Moses: The Hunt for the World's Oldest Bible (New York: HarperCollins, 2016), 316-318. 


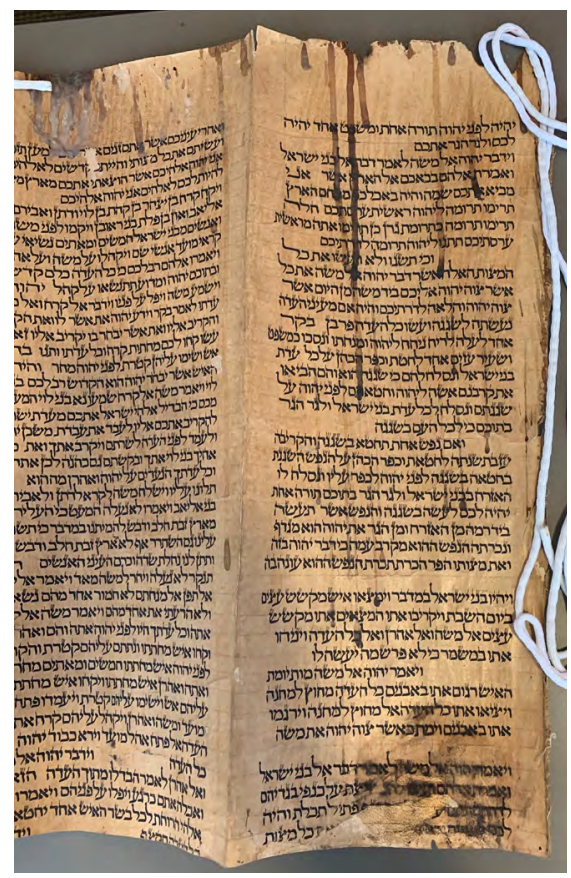

Brinner 11, showing water damage

Courtesy: Sutro Library, San Francisco

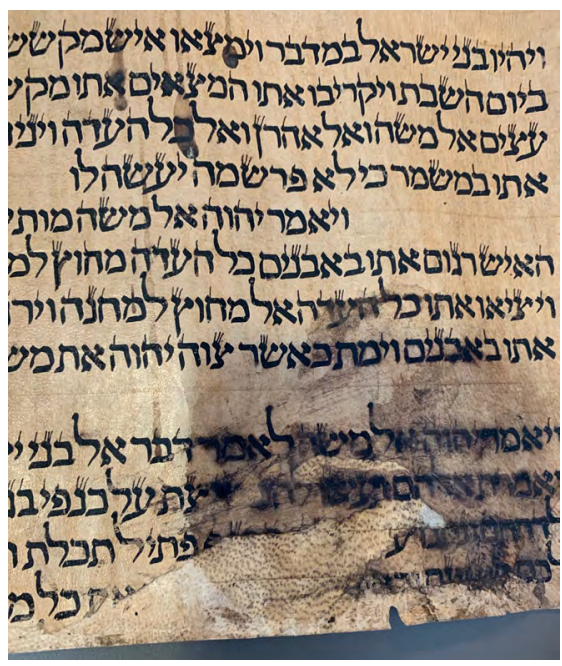

Detail of Brinner 11, showing severe water damage in lower portion

Courtesy: Sutro Library, San Francisco

Tigay's interpretation does not appear to be correct. As is evident from the photographs, this scroll, like several others in the collection, suffered substantial water damage, especially in its lower portion. Water penetrated from above, leaving behind inky drip marks, as seen in the left-hand image. This water then pooled at the bottom, where the worst damage-both direct and due to subsequent rotwould have been concentrated. Indeed, as seen in the right-hand image, the degradation at the lower edge was severe and extended even above the (now excised) blank lower margin. It therefore seems that the margin was cut off to stem the rot and prevent further damage to the scroll, rather than to create a stout blank manuscript for the purpose of forgery. ${ }^{30}$

To summarize, the cut-margin theory of Clermont-Ganneau and Ginsburg was problematic from the start, and in all the years since, no viable corroborating evidence has been found. Nevertheless, their assessment was immediately

30 See page 7, above, for a first-hand report describing the leather of the Shapira fragments as much thicker than that of Torah scrolls and making no note of water damage. 
accepted by scholars and the general public, and it has never been successfully overturned.

Here we see a cartoon from the popular Punch magazine, in which Ginsburg apprehends the hook-nosed Shapira, the villain's finger still dripping with the ink of his fresh counterfeit. ${ }^{31}$

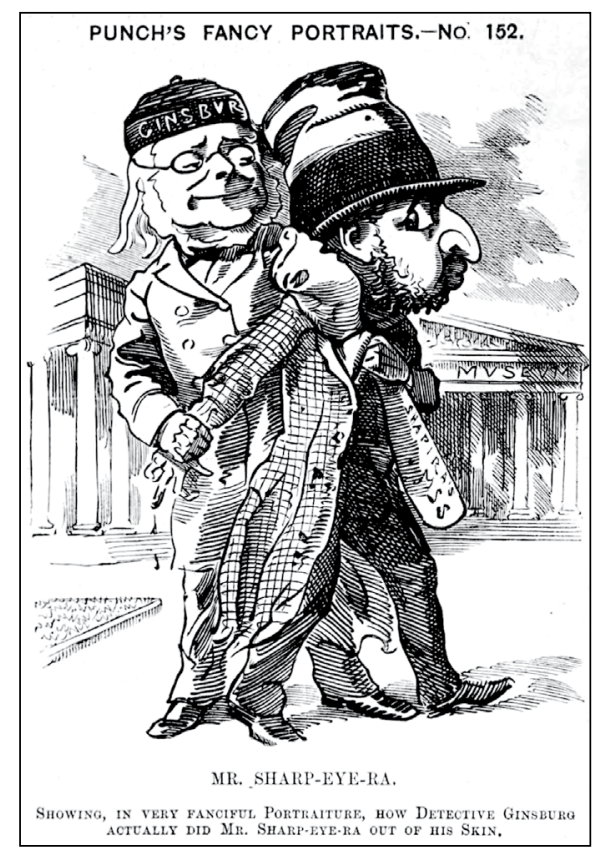

After this disgrace, Shapira abandoned his manuscripts at the British Museum. Before leaving town, he wrote a letter to Ginsburg:

\section{Dear Dr. Ginzberg!}

You have made a fool of me by publishing \& exhibiting things that you believe them to be false. I do not think I will be able to survive this shame. Although I am yet not convince[d] that the M.s. is a forgery unless M Ganneau did it!

I will leave London in a day or two for Berlin.

Yours truly,

M W Shapira ${ }^{32}$

31 Punch, or the London Charivari (September 8, 1883): 118.

32 BL Ms. Add. 41294, 16. 
The British Museum appears to have shared the contents of this letter with The Times, which proceeded to publish the following: »[Shapira] is so disappointed with the results of his bargain that he threatens to commit suicide. This, we venture to think, he will not do. ${ }^{33}$

Shapira never returned home to his family. After wandering for months through Europe, he shot himself in the head in a Rotterdam hotel.

\section{Paleography}

In recent years, a new argument has emerged against the authenticity of the Shapira fragments, this time by epigraphers. According to these critics, the paleography of the manuscripts plainly betrays the work of a forger. Most prominently, André Lemaire wrote the following in a piece titled »Paleography's Verdict: They're Fakes!«:

Paleographical analysis reveals the work of at least two different scribes. However, the letter shapes do not correspond exactly to any known ancient West Semitic script. It is neither Moabite (although most letters seem like imitations of Moabite writing in the Mesha Stele, which records the ninth-century B.C.E. Moabite king Mesha's victories over Israel; photo and detail of drawing, below) nor "Canaanite « (West Semitic writing from about the 13th to the 11th century B.C.E.). It is neither the Hebrew script used during the First Temple period nor the archaizing paleo-Hebrew script found on coins of the First Jewish Revolt against Rome (66-70 C.E.) and the Second Jewish Revolt (132-135 C.E.) and in several of the Dead Sea Scrolls. In truth, after a simple look at the facsimile, an experienced paleographer can see it is a forgery. ${ }^{34}$

Lemaire's discussion obscures a fundamental methodological problem with the entire enterprise of epigraphic analysis in this particular case: The fragments are no longer extant. Lemaire's study is not an analysis of the Shapira manuscripts; it is an analysis of a nineteenth-century drawing. Moreover, as we will see, this drawing is demonstrably unreliable.

In his article, Lemaire reproduces a drawing of Fragment E commissioned by Ginsburg. In fact, it appears to be an early draft of the rendering. Be that as it may, it is markedly different from other versions of the same drawing. ${ }^{35}$

33 The Times (August 27, 1883): 7.

34 André Lemaire, »Paleography’s Verdict: They’re Fakes!« Biblical Archaeology Review 23/3 (1997): 36-38: 38 (My emphasis).

35 The versions of Ginsburg's drawing can be found BL Ms. Add. 41294, 34 (top and bottom), 35 (top and bottom), 36 (top and bottom), 37 f.; Christian David Ginsburg, »The Shapira Ms. of Deuteronomy, « The Athenæum 2915 (September 8, 1883): 304 f.: 305. 


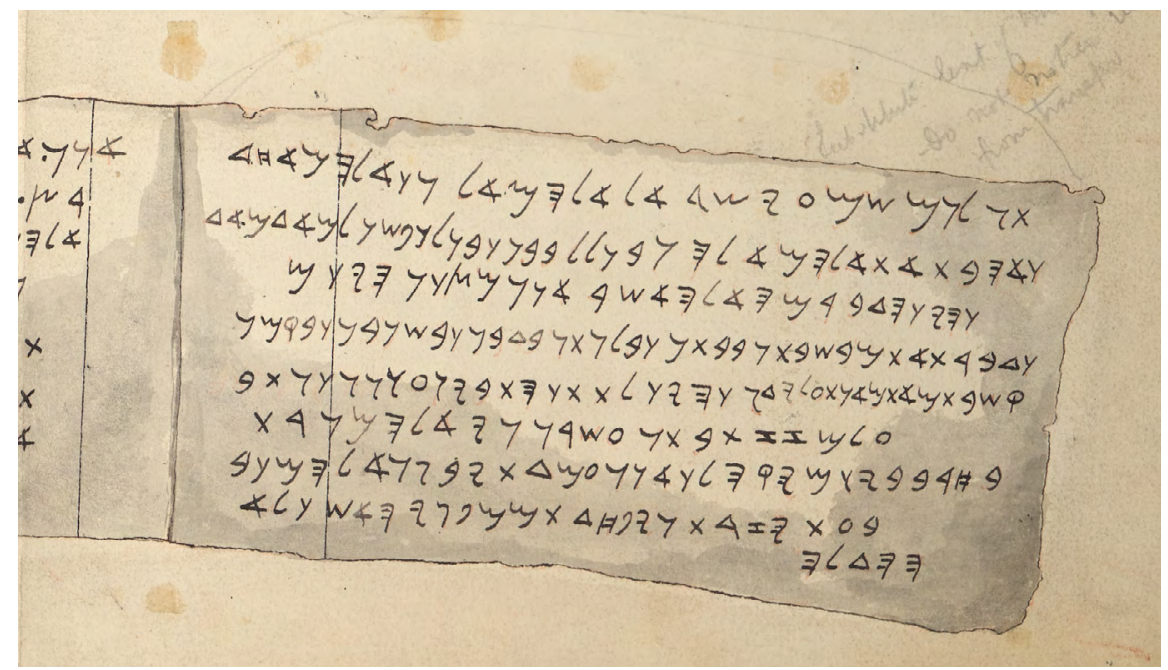

The draft of Ginsburg's drawing reproduced in Lemaire's article (BL Ms. Add. 41294, 35. By permission of the British Library).

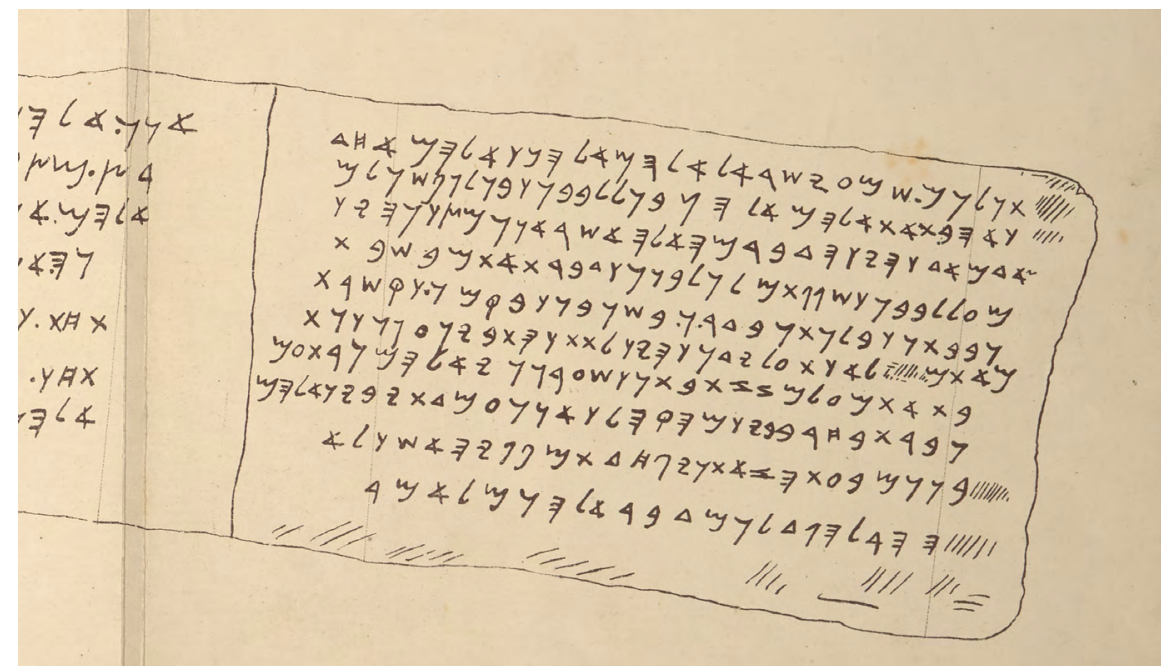

A different draft of Ginsburg's drawing of the same column

(BL Ms. Add. 41294, 34. By permission of the British Library). 
Compare the two versions below: The differences between these two versions are too numerous to list; I will detail only a few. In one of the Ginsburg drafts, line 2 ends with למאד מאד. In the other, the same line ends five letters earlier with למ, the remainder of the phrase now appearing at the beginning of line $3 .^{36}$ This discrepancy concerns the fundamental layout of the fragment, and similar disparities abound. Moreover, a comparison of these two drafts calls into question the possibility of conducting any fruitful second-hand paleographic analysis. For instance, the two images below show details of the word בין in Va1:8, ${ }^{37}$ as represented in the two drafts above:

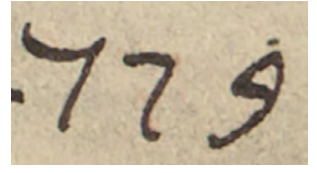

בin the draft reproduced in Lemaire's article (BL Ms. Add. 41294, 35)

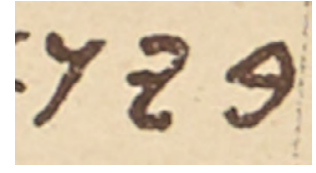

בין in a different draft

(BL Ms. Add. 41294, 34)

Even though these are meant to be representations of the very same spot on the very same manuscript fragment, not one of the three letters is paleographically comparable in the two drawings. The same can be said for the word הזאת in Va E1:8:

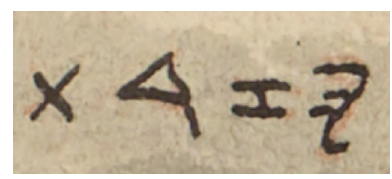

in the draft reproduced in Lemaire's article

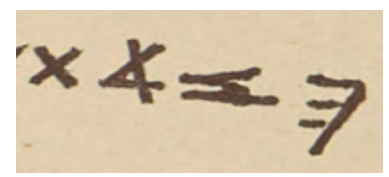

in a different draft

(BL Ms. Add. 41294, 34)

(BL Ms. Add. 41294, 35)

This exercise can be repeated for any word in these two drafts, and additional distinct drafts could be introduced as well. ${ }^{38}$

There are other reasons to be wary of treating these drawings as original artifacts. A common feature throughout Ginsburg's drafts of Fragment $\mathrm{E}$ is his rep-

36 This is the correct layout, as corroborated by Guthe, Lederhandschrift, 34.

37 All citations of The Valediction of Moses are from the critical edition published in Idan Dershowitz, The Valediction of Moses: A Proto-Biblical Book, FAT I/145 (Tübingen: Mohr Siebeck, 2021).

38 See note 35. 
resentation of $v a v$, which is written with two diagonal strokes and resembles a lowercase »y«. In Guthe's table of the letterforms in this very fragment, ${ }^{39}$ he represents the vav rather differently: It is written with what appear to be three strokes, producing a much narrower, more vertical, and more symmetrical letterform.
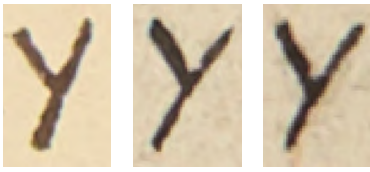

Examples of vav in Ginsburg's drawings of Fragment $E\left(V^{a}\right)$

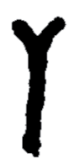

Vav in Guthe's table of letterforms in Fragment $\mathrm{E}(\mathrm{V})$

The differences between Ginsburg's and Guthe's representations of the qoph in Fragment E are no less striking. In Ginsburg's drawings, the qoph is consistently drawn as a circle intersected by a vertical stroke. ${ }^{40}$ In Guthe's drawing of the qoph letterforms in this fragment, not only is the vertical stroke substantially longer than in Ginsburg's drawings, but it also clearly does not intersect the circle. Indeed, Guthe says as much explicitly in his discussion of the letter, drawing attention to the distinctiveness of this specific feature. ${ }^{41}$
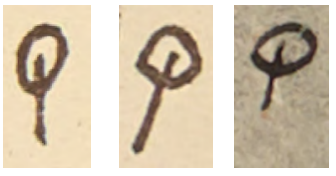

Examples of qoph in Ginsburg's drawings of Fragment $E\left(V^{a}\right)$

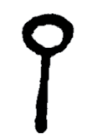

Qoph in Guthe's table of letterforms in Fragment $\mathrm{E}\left(\mathrm{V}^{\mathrm{a}}\right)$

There is one additional means to ascertain the accuracy of Ginsburg's drawings. As it happens, Ginsburg published his own "facsimile« of the Mesha Stele as well. ${ }^{42}$ Fortunately, much of the stele remains, as do a very early paper squeeze and various plaster casts. Juxtaposing Ginsburg's version with the original object and its direct impressions leaves no room for doubt: Ginsburg's drawings are utterly undependable for paleographic purposes.

39 Guthe, Lederhandschrift, appendix.

40 There is, however, no consistency vis-à-vis stance.

41 Guthe, Lederhandschrift, 67.

42 Christian David Ginsburg, The Moabite Stone: A Fac-simile of the Original Inscription, with an English Translation, and a Historical and Critical Commentary (London: Reeves and Turner, $\left.{ }^{2} 1871\right)$. 


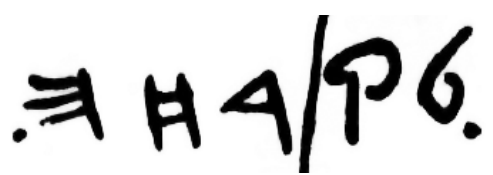

in Ginsburg's facsimile of the Mesha Stele (line 25)

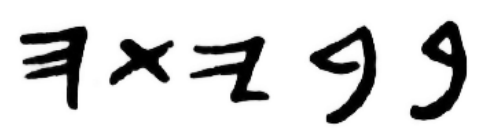

in Ginsburg's facsimile of the Mesha Stele (line 25)

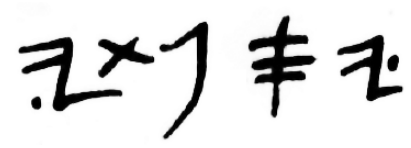

יספתי in Ginsburg's facsimile of the Mesha Stele (line 29)

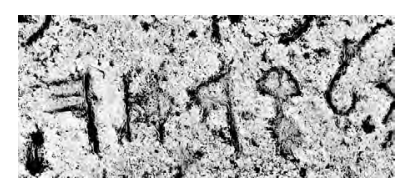

in paper squeeze

of the Mesha Stele (line 25)

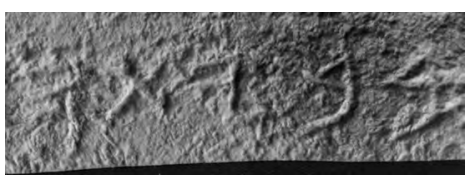

in paper squeeze

of the Mesha Stele (line 25)

(Image courtesy of the Louvre Museum)

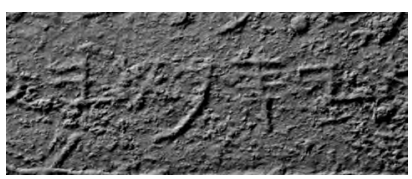

in paper squeeze

of the Mesha Stele (line 29)

(Image courtesy of the Louvre Museum)

Even though Ginsburg had ostensibly created a facsimile of the stele, we can see that his letterforms are written with little regard for the original characters' relative size, position, stance, shape, and ductus. The bet in Ginsburg's drawing of the Mesha Stele, for instance, has a curved base, whereas in the original, it has an angular joint. Ginsburg's samek has a vertical stroke that intersects the upper horizontal stroke, while in the stele itself, the letter has a flat head. The two sameks also differ in stance, with the original leaning to the left and Ginsburg's leaning to the right.

The properties that stand out to paleographers as problematic in the Shapira manuscript may, therefore, be characteristics of the drawings, not the objects. Indeed, the same curved base of the bet, for instance, features in Ginsburg's drawings of the Shapira manuscripts. ${ }^{43}$

43 I thank David Vanderhooft for bringing to my attention the seemingly problematic form of this letter. 

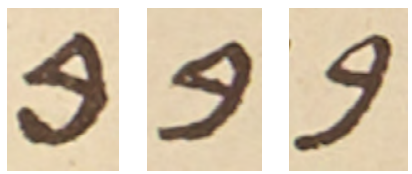

Examples of bet in Ginsburg's drawings of Fragment $\mathrm{E}(\mathrm{V})$

While paleographic analysis is typically essential for the purposes of authentication and dating, this is not the case for the Shapira manuscripts, considering that the original objects are lost. We do not have even a single photograph of the manuscripts in which text is discernible, and we have seen that Ginsburg's drawings are unreliable and mutually contradictory. This is not to say that paleography has nothing at all to contribute. Guthe's descriptions and discussion are considerably more useful than Ginsburg's drawings, for example, although they too cannot be taken at face value. Most iluminating of all are the naive drawings prepared by artists who were not literate in Paleo-Hebrew, which have been largely overlooked. Ginsburg and Guthe were well versed in the paleographic curriculum of their generation, and that knowledge appears to have influenced how they saw and represented the script of the Shapira manuscripts. Illiterate artists, on the other hand, are largely immune to such pattern-recognition hazards.

This brings me to my final example. One paleographic oddity in Ginsburg's drawings of the Shapira manuscripts is the right-leaning stance of the $h e{ }^{44}$

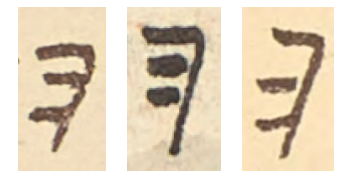

Examples of he in Ginsburg's drawings of Fragment $\mathrm{E}\left(\mathrm{V}^{\mathrm{a}}\right)$

While not without precedent in ancient inscriptions, this stance is nevertheless uncommon. It therefore might be seen as a revealing an error by a forger who was not attuned to stance, given that it was not a well-understood phenomenon in the nineteenth century.

44 I thank Christopher Rollston and Michael Langlois for highlighting this apparent paleographic problem with the Shapira manuscripts. The same applies, to a lesser extent, to the letterforms drawn by Guthe. 
However, in a drawing published in The Graphic in 1883 and prepared by a non-specialist artist, ${ }^{45}$ we can see three very clear he characters. Unlike in Ginsburg's drawings, where the letter has a right-leaning orientation, here each he leans unmistakably to the left.

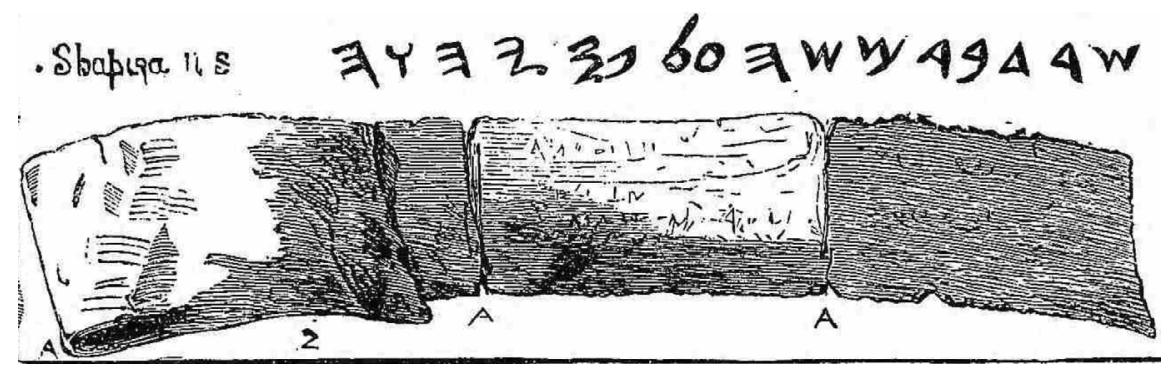

Illustration from The Graphic (1883)

Another detail in this drawing that differs from the renderings by Ginsburg and Guthe is the flourish, or reflex, on the bottom-right of the two yods. This feature is now attested in the epigraphic record, especially among the Samaria ostraca. ${ }^{46}$

In sum, Lemaire is correct that a cursory look at the paleography of the Shapira manuscripts-as reproduced in Ginsburg's drawings-suggests that they are forgeries. This does not, however, tell us what the outcome of an analysis of the original fragments would have been. Indeed, in a world in which the unquestionably genuine Mesha Stele were lost and only Ginsburg's facsimile remained, paleographers using the very same reasoning would condemn it too as a forgery. And they would be wrong.

45 The Graphic (September 1, 1883): 224.

46 See Frank Moore Cross, Jr., »Epigraphic Notes on Hebrew Documents of the Eighth-Sixth Centuries B. C.: II. The Murabba'ât Papyrus and the Letter Found near Yabneh-yam, « BASOR 165 (1962): 34-46: 36; Ivan Tracy Kaufman, The Samaria Ostraca: A Study in Ancient Hebrew Palaeography (PhD diss., Harvard University, 1966), 45-48. The first of the two yods in this drawing has been drawn with a single stroke. It is notable that although single-stroke yods are very uncommon, they are, in fact, attested multiple times in the Samaria corpus (Kaufman, »Ostraca«: 46) and perhaps also in an early inscription from Tel Rehov (Amihai Mazar, »Three 10th-9th Century B.C.E. Inscriptions from Tēl Rehōv, « in Saxa loquentur: Studien zur Archäologie Palästinas/ Israels. Festschrift für Volkmar Fritz zum 65. Geburtstag, ed. Cornelis G. den Hertog et al., AOAT 302 [Münster: Ugarit Verlag, 2003]: 171-184: 179). None of these inscriptions had been unearthed in Shapira's lifetime. I thank Benjamin Sass for bringing this feature of the Tel Rehov inscription to my attention. 


\section{The Shapira Papers}

In 1887, three years after Shapira committed suicide, his widow, Anna Magdalena Rosette, gave a number of his documents to Hermann Strack, who passed them on to the Königliche Bibliothek (now the Staatsbibliothek in Berlin). These documents included several notebooks cataloging and describing manuscripts from Yemen and Egypt that Shapira had offered for sale. These were bound together into a volume and given the title, "Shapiras eigenhändiges Verzeichnis der von ihm gesammelten hebraeischen Handschriften« or »Shapira's handwritten index of the Hebrew manuscripts collected by him. ${ }^{47}$

A number of miscellaneous loose sheets were bound together with the notebooks. ${ }^{48}$ Some of these give the text of piyyutim in his collection, and one lists ten items for sale from the »Geniza of Kairo«-several years before the corpus attracted scholars' attention.

Of greatest interest for our purposes are three ruled sheets, none of which has any heading or description, which are scattered haphazardly and out of sequence among the several hundred pages of the volume. Combined, they constitute an early transcription, in Shapira's own handwriting, of much of V.

This transcription, which has not been previously identified, is highly illuminating and goes a long way toward exonerating Shapira. It contains a great number of question marks, marginal musings, and rejected readings; it appears to be a preliminary decipherment. ${ }^{49}$ Indeed, Shapira was still in the process of working out the correct order of the inscribed leather fragments as he prepared on this draft; after transcribing five columns, Shapira noted that his »column 6 « belonged, in fact, before »column 3«. Notably, Shapira's reading of V also contains a number of mistakes. Shapira's evident struggle to understand the text undermines the plausibility of the hypothesis that he was involved in the forgery of the manuscripts.

One revealing error is Shapira's misreading of the word וישמ[ד]ם below as וישם [את] (The pilcrow [Ф] indicates a line break).

47 Ms. or. fol. 1342. It is listed today as Eigenhändiges Verzeichnis der von Shapira gesammelten hebr. Handschriften. I am grateful for the assistance of Petra Figeac and Sophia Fock at the Staatsbibliothek.

48 A note at the beginning of the volume says that the loose sheets were compiled by Moritz Steinschneider.

49 That this is an early draft can also be inferred from a comparison with Shapira's later writings. In a letter from August 1883 (BL Ms. Add. 41294, 21), Shapira writes that he had previously read a certain string of letters (located in B1:1) וינאף (metathesis of ויאנף), only to realize later

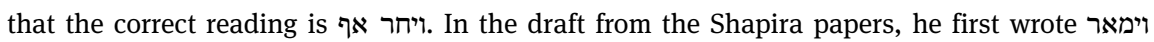
(ויאמר וינאף וירוי (metathesis, crossed it out, and replaced it with, the earlier reading Shapira refers to in his letter is the corrected reading here. 


\section{Deut 20b-21 (MT)}

רפאים ישבו בה לפנים והעמנים יקראו להם זמזמים עם גדול יפנים והעים ורב ורם כענקים וישמידם זידם יהוה גירוה מפניהם ויירשם וישבו תחתם וישמידוה ירורים
Shapira's transcription of $V$ Va D1:8-9

[רפ]אם מעלם ישבו בה והעמנם יקראו להם עזמזמם וישם ישבו ורעם תחאת]ם אלהם מפנהם וישבו

תחתם

\section{Corrected transcription of $\mathrm{V}$} Va D1:8-9

[רפ]אם מעלם ישבו בה והעמנם

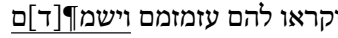
אלהם מפנהם וישבו תתחם

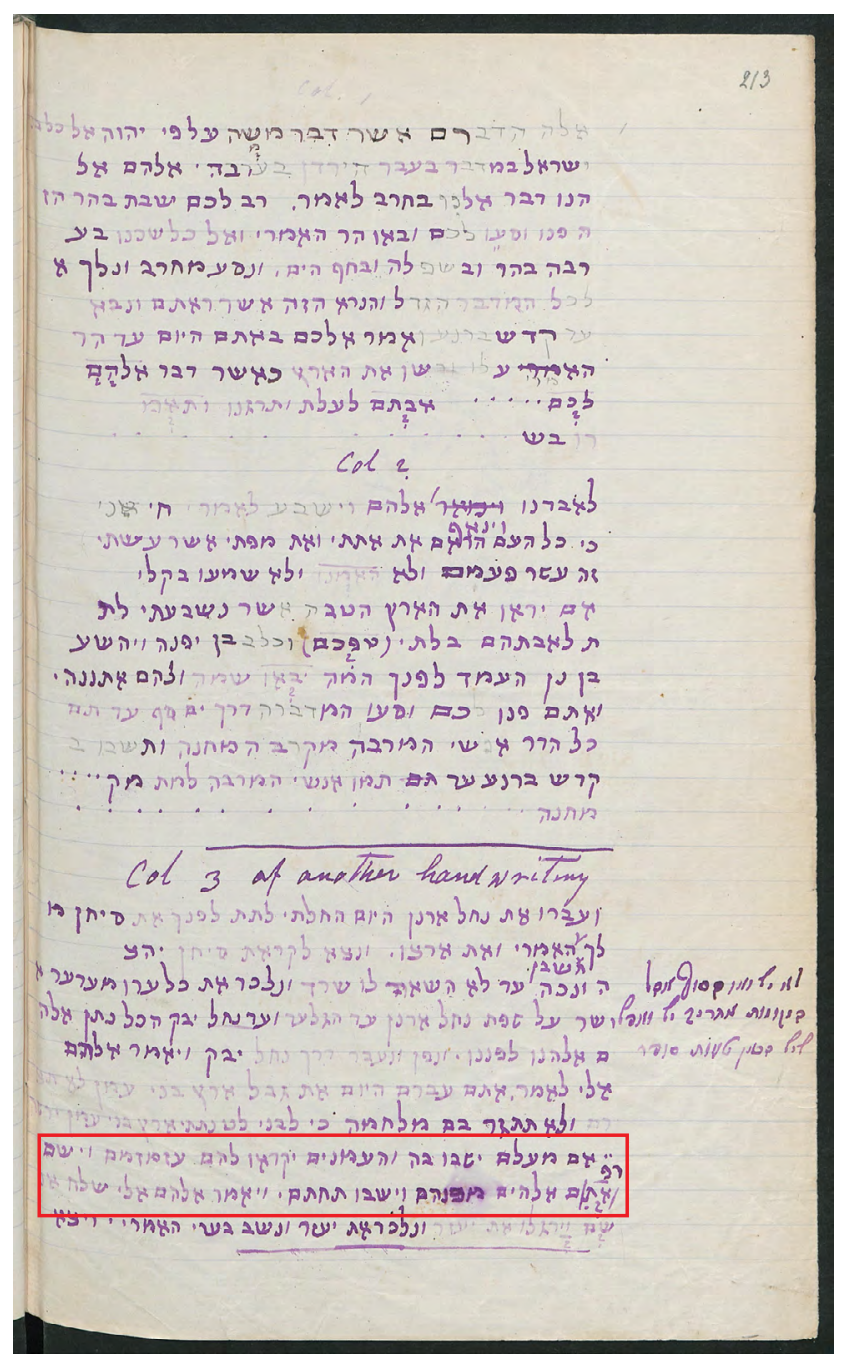

Leaf from Shapira's transcription of $\mathrm{V}$, with erroneous reconstruction highlighted Courtesy Staatsbibliothek Berlin 
To help illustrate the error, consider that the relevant portion of the manuscript from which Shapira was reading $\left(\mathrm{V}^{\mathrm{a}}\right)$ would have looked something like this:

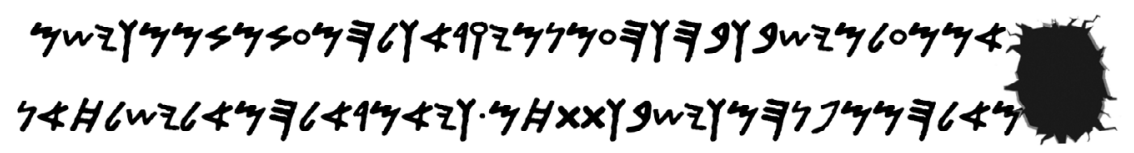

Shapira may have been thrown off by the scriptio continua (and the resulting potential for words to be broken between lines) and the absence of terminal letterforms. $^{50}$ The final four letters of the upper line form a familiar Hebrew word, וישם, and Shapira appears to have overlooked the possibility that the word did not end at the line break. Both lines begin with a small lacuna, and the first letter on the lower line-mem-is followed by the word Elohim (אלהם). Shapira seems to have sought a short word ending with a mem to fit the space and provisionally reconstructed an aleph and tav, marking them with a question mark.

While the etiology for this error is easy to reconstruct, it raises an obvious question. If Shapira was the forger-or one of the forgers-of the manuscripts, why do his private papers include a not-altogether-successful attempt at deciphering them? It would surely be unusual for a forger to labor to understand a text that he himself had devised or inscribed..$^{51}$

At minimum, these documents seem to suggest that Shapira believed the manuscripts to be authentic, and that he was previously unfamiliar with their contents. If the manuscripts are indeed forgeries, Shapira was likely the victim of the hoax, not its perpetrator.

This, in turn, raises new questions as to the possible motive for the supposed forgery, as well as its feasibility. It is no coincidence that Shapira has always been personally implicated-whether explicitly or not-in the forgery of these manu-

50 For a description of the manuscripts, see the introduction to my critical edition.

51 Several other misapprehensions of $\mathrm{V}$ by Shapira are evident in this transcription and elsewhere. I will briefly outline one more, which relates to the proper delineation of the ten commandments (or better, proclamations). In a letter to Hermann Strack, Shapira wrote that the first proclamation in V is לא תעשה your [sic] shall have no other gods« (BL Ms. Add. 41294, 7). Whether Shapira intended לא תעשה, as in the Hebrew, or לא להיה, as in his translation, he was incorrect. The layout of the Decalogue in $\mathrm{V}^{\mathrm{a}}$, which is preserved in numerous drawings, shows אנכי : (יהוה אלהיך). Each proclamation starts a new line, and the only pertinent line break in the vicinity appears before אנר (יהלה Guthe made a similar error and marked »Thou shalt have no other gods before me« as the beginning of the first proclamation (Guthe, Lederhandschrift, 34). Both Guthe and Shapira may have been influenced by traditions that construe אנכי as a preamble. 
scripts. After all, he had an obvious motive: enormous wealth and prestige. He also appears to have had a fitting personal history, which included the sale of inauthentic Moabite pottery. ${ }^{52}$ Furthermore, the text of $\mathrm{V}$ was said to contain errors made by a person of European Jewish extraction, ostensibly incriminating Shapira. ${ }^{53}$ Lastly, the manuscripts were also said to have been cut from the bottom margins of oriental Torah scrolls, of which Shapira was a major purveyor. ${ }^{54}$ None of these arguments is tenable any longer.

Had it been the case that Shapira knew the manuscripts to be forgeries, then his tales of discovery and purchase would, of course, have been lies. This has long been the presumption among scholars. But since Shapira apparently believed the manuscripts to be genuine, it is difficult to account for his testimony or, indeed, to conjure any coherent narrative regarding the putative forgery. As noted above, Shapira stated that he had purchased the leather manuscripts from Bedouins who had found them in a cave by the Dead Sea, wrapped in linen bundles and covered in a bitumen-like substance. If all this was a ruse to dupe Shapira, what then motivated the mastermind? Are we to believe that a forger invested tremendous time, effort, and funds to create two fraudulent manuscripts (and a fragment of a third), only to sell them to Bedouins for a pittance $?^{55}$

Moreover, an anonymous forger would not have earned a penny from the fortunes that Shapira stood to gain from a successful sale of the manuscripts to the British Museum. Such a forger would also have had no obvious opportunity to gain fame as anything other than a fraud. Lastly, as noted below, the text of $\mathrm{V}$ corresponds to no scholarly opinion or theory that existed at the time, ruling out vindication of a particular scholar as a plausible motive. As observed by the anonymous author of a learned Daily News article from 1883: „One considerable argument in favour of the genuineness of the manuscripts results from the fact that it agrees with no school of theological or critical opinion. $«^{56}$

\section{See note 3.}

53 For a dismantling of this argument, see Mansoor, »Shapira’s Dead Sea Scrolls«: 214-217.

54 See above.

55 According to Shapira, he paid very little for the fragments: »I confess; that when getting prof. S. [= Schlottmann] letter I begin [sic] to totter in my opinion, not so much for the last reason [that is Aramaic, not Hebrew], as for the general reason the prof. gives, that it contradicts our Bible; Of course, my 1st question I had ask [sic] myself was, if it is by all means a forgery who could have been such a learned \& artful forger? \& for what purpose? as the mony [sic] I paid for the M.s.s was not worth the speaking of (BL Ms. Add. 41294, 5).

56 The Daily News (August 22, 1883): 3. 


\section{Conclusion}

For more than a century, there has been a robust consensus that the Shapira manuscripts are fraudulent and that Shapira was involved in their forgery. We have now seen that the evidence underpinning this judgment does not stand up to scrutiny. Shapira's heretofore unknown private transcription further undermines the prevailing narrative, as it makes clear that Shapira was himself unfamiliar with the text that he had supposedly fabricated.

But that is not all. In a companion monograph, I provide a critical edition of the composition preserved in the Shapira manuscripts, which I call »The Valediction of Moses « or »V«, and offer a detailed analysis of the text and its relation to the canonical book of Deuteronomy. ${ }^{57}$ This analysis shows $\mathrm{V}$ to be of a radically different nature than has previously been thought. Specifically, this work is not derivative of Deuteronomy. On the contrary, the text contained in Shapira's fragments is either a direct ancestor of the biblical book of Deuteronomy or a close relative of such an ancestor. Several passages in V were supplemented and gradually altered until they took on their familiar biblical forms. In fact, the text of $\mathrm{V}$ regularly accords with source-critical analyses that were introduced only after Shapira's time, meaning that these insights were unavailable to any potential forger. The great antiquity of $\mathrm{V}$ is further supported by its inclusion of early versions of biblical narratives whose canonical counterparts contain post-Priestly supplements. Moreover, the Deuteronomic law code-echoes of which reverberate throughout the canonical narratives of Deuteronomy-appears to have had no influence upon V. Indeed, V preserves an earlier and dramatically different literary structure for the entire work-one that lacked the Deuteronomic law code altogether.

In addition to the above, the book lays out several rich intertexts between the Valediction of Moses and various segments of the Hebrew Bible. A chapter co-authored with Na'ama Pat-El examines the linguistic profile of V, which we find to be consistent with First Temple-era epigraphic Hebrew.

Beyond the manifest ramifications for the composition history of the Pentateuch, these findings have significant consequences for several disciplines, ranging from geography to paleography to the history of religion.

57 Idan Dershowitz, The Valediction of Moses: A Proto-Biblical Book, FAT I/145 (Tübingen: Mohr Siebeck, 2021). 
Abstract: Wilhelm Moses Shapira's infamous Deuteronomy fragments have long been deemed forgeries, with Shapira himself serving as the obvious suspect. I provide new evidence that Shapira did not forge the fragments and was himself convinced of their authenticity. Indeed, the evidence for forgery is illusory. In a companion monograph, I show that the Shapira fragments are not only authentic ancient artifacts but are unprecedented in their significance: They preserve a pre-canonical antecedent of the Book of Deuteronomy.

Keywords: Deuteronomy, Dead Sea Scrolls, DSS, Shapira.

Zusammenfassung: Wilhelm Moses Shapiras berüchtigte Deuteronomium-Fragmente sind lange Zeit für Fälschungen gehalten worden, wobei zumeist Shapira selbst als Urheber verdächtigt wurde. Ich erbringe neue Nachweise dafür, dass Shapira die Fragmente nicht gefälscht hat, sondern selbst von deren Echtheit überzeugt war. Vielmehr sind die Beweise für eine Fälschung als illusorisch einzuschätzen. In einer Monographie mit kritischen Textausgaben der Shapira-Fragmente weise ich nach, dass diese nicht nur authentische antike Artefakte, sondern beispiellos in ihrer Bedeutung sind: Sie bewahren einen vorkanonischen Vorläufer des Buches Deuteronomium.

Schlüsselwörter: Deuteronomium, Schriftrollen vom Toten Meer, DSS, Shapira.

Résumé: Les fragments tristement célèbres de Deutéronome de Wilhelm Moses Shapira ont longtemps été considérés d'être contrefaçons, Shapira lui-même étant le suspect évident. Je fournis de nouvelle preuve que Shapira n'a pas falsifié les fragments et qu'il était lui-même convaincu de leur authenticité. En fait, la preuve de la falsification est illusoire. Dans une monographie complémentaire, je montre que les fragments de Shapira ne sont pas seulement des artefacts anciens authentiques, mais qu'ils sont d'une importance sans précédent: ils preservent un antécédent pré-canonique du Livre du Deutéronome.

Mots-clés: Deutéronome, rouleaux de la mer morte, DSS, Shapira. 